\title{
Volatile compounds profile of Bromeliaceae flowers
}

\author{
Everton Hilo de Souza ${ }^{1 *}$, Adna P. Massarioli ${ }^{2}$, Ivani A. M. Moreno ${ }^{2}$, Fernanda V. D. Souza ${ }^{3}$, \\ Carlos A. S. Ledo ${ }^{3}$, Severino M. Alencar ${ }^{2}$ \& Adriana P. Martinelli ${ }^{1 *}$ \\ 1. University of São Paulo (CENA), Av. Centenário 303, 13416-903, Piracicaba, SP, Brazil; hilosouza@gmail.com, \\ adriana@cena.usp.br \\ 2. University of São Paulo (ESALQ), Av. Pádua Dias 11, 13418-900, Piracicaba, SP, Brazil; adnaprado@usp.br, \\ imoreno@usp.br, smalencar@usp.br \\ 3. Embrapa Cassava and Fruits, Rua Embrapa s/n, 44380-000, Cruz das Almas, BA, Brazil; \\ fernanda.souza@embrapa.br, carlos.ledo@embrapa.br
}

\section{Received 16-III-2015. Corrected 07-III-2016. Accepted 01-IV-2016.}

\begin{abstract}
Volatile compounds play a vital role in the life cycle of plants, possessing antimicrobial and anti-herbivore activities, and with a significant importance in the food, cosmetic, chemical, and pharmaceutical industry. This study aimed to identify the volatile compounds emitted by flowers of thirteen species belonging to four genera of Bromeliaceae, using headspace solid-phase micro-extraction and detection by gas chromatography-mass spectrometry. A total of 71 volatile compounds belonging to nine chemical groups were identified. The compounds identified represented more than $97 \%$ of the major components in Aechmea bicolor, Ae. bromeliifolia, Ae. distichantha, Ae. fasciata, and Vriesea friburgensis. In the Ananas varieties, over $99 \%$ of the components were identified, and around $90 \%$ in $V$. simplex. V. friburgensis presented the largest diversity of volatiles with 31 compounds, while Alcantarea nahoumii presented only 14. All three Ananas varieties presented the same 28 compounds in relatively similar abundance, which has been confirmed by principal component analysis. Current taxonomy and pollination syndrome studies available can adequately explain the variation in volatile compounds among species. Rev. Biol. Trop. 64 (3): 1101-1116. Epub 2016 September 01.
\end{abstract}

Key words: Bromeliaceae, gas chromatography, headspace, mass spectrometry, principal component analysis, terpenoids, volatile compounds.

Bromeliaceae Juss family belongs to the Poales order, with 58 genus and 3352 species (Luther, 2012). Bromeliaceae presents a wide diversity of forms and are found in almost every neotropical ecosystem, from sea level in beaches, mangroves, and shoals to altitudes of $4000 \mathrm{~m}$ above sea level in the Andes (Benzing, 2000).

Volatile compounds are critical for the plant life cycle, especially for pollination and seed dispersion, which assures plant reproduction and their evolutive success (Pichersky \& Gershenzon, 2002; Knudsen \& Gershenzon, 2006; Suinyuy, Donaldson, \& Johnson, 2013; Aguilar-Rodriguez et al., 2014). Hummingbirds pollinate most of the bromeliad species, with flowers presenting colorful and attractive bracts and abundant nectar (Benzing, 2000; Kessler \& Krömer, 2000; Araujo, Fischer, \& Sazima, 2004). Bats are also notable pollinator agents in some species that present scented flowers, of nocturnal anthesis (Sazima, Vogel, \& Sazima, 1989; Knudsen \& Tollsten, 1995; Sazima, Buzato, \& Sazima, 1995; Aguilar-Rodríguez et al., 2014). In addition to ornithophily and chiropterophily, there are also records of pollination of Bromeliaceae by butterflies, bees, and beetles (Benzing, 2000; Kessler \& Krömer, 2000; Canela \& Sazima, 2005; Siqueira Filho \& Machado, 2001; Schmid, Schmid, Zillikens, 
\& Steiner, 2011). The majority of Bromeliaceae has scentless flowers, except in a few cases such as Hohenbergia ridleyi (Baker) Mez. (Siqueira Filho, 1998); in Tillandsia crocata (E. Morren) Baker (Gerlach \& Schill, 1991); Canistrum aurantiacum E. Morren (Siqueira Filho \& Machado, 2001); Puya sp. (Knudsen, Tollsten, Groth, Bergström, \& Raguso, 2004; Bromelia antiacantha Bertol. (Canela \& Sazima, 2005), and Tillandsia macropetala Wawra (Aguilar-Rodríguez et al., 2014). In these species, a delicate and sweet scent is associated with bee pollination. On the other hand, Encholirium glaziovii Mez and some Vriesea have an unpleasant scent and copious amounts of nectar, attracting bats (Sazima et al., 1989; Sazima et al., 1995). Bromelia antiacantha Bertol. flowers have a strong sweet scent which becomes lighter throughout the day (Canela \& Sazima, 2005). Tillandsia macropetala Wawra flowers are pollinated by bats and present faintly sweet odor in the early hours of the night, when the nectar volume is the highest (Aguilar-Rodriguez et al., 2014).

These compounds may possess antimicrobial and antiherbivore activity, also repelling microorganisms and animals or attracting natural predators, protecting the plant through tritrophic interactions (Hammer, Carson, \& Riley, 2003; Arab \& Bento, 2006; Lucas-Barbosa, Loon, \& Dicke, 2011), which also suggests their involvement in the protection of the reproductive parts of plants during flowering (Kessler, Halitschke, \& Poveda, 2011; ParraGarcés, Caroprese-Araque, Arrieta-Prieto, \& Stashenko, 2010). On the other hand, like all inheritable characters, chemical compounds that make up scents may also reflect the taxonomic affinities of a species. The characterization of volatile compounds may contribute to taxonomic and phylogenetic studies considering that some volatile compounds may be specific to certain plant groups (see for example Nogueira, Bittrich, Shepherd, Lopes, \& Marsaioli, 2001).

Volatile compounds also have significant importance in the food industry, cosmetics, perfumes, chemical and pharmaceutical industries
(Dudareva \& Pichersky, 2006; Cheng, 2010; Darjazi, 2011; Paibon et al., 2011), due to the increased preference for natural food additives and other compounds of biological origin (Huang, Lee, \& Chou, 2001). These are mainly terpenoids, phenylpropanoids, hydrocarbons, alcohols, aldehydes, ketones, ethers and esters derived from fatty acids, representing approximately $1 \%$ of the known secondary metabolites in plants (Dudareva, Pichersky, \& Gershenzon, 2004). In the Bromeliaceae family, volatile compounds were studied in the Ananas genus and mostly the fruit volatile compounds. In Ananas over 280 compounds were identified, the most abundant being esters, terpenes, ketones and aldehydes (Tokitomo, Steinhaus, Suttner, \& Schieberle, 2005; Liu, Wei, Sum, \& Zang, 2008; Wei et al., 2011). Aguilar-Rodríguez et al. (2014) identified nine volatile compounds (three fatty acid derivatives and six terpenoids) in T. macropetala, and correlated their presence to bat-pollination during a study of floral and reproductive biology.

This study aims to identify volatile compounds from flowers of thirteen ornamental species belonging to four genera of Bromeliaceae (using headspace solid-phase micro-extraction with detection by gas chromatography-mass spectrometry), and to bring a new contribution revealing the potential that these plants have in the industry, in the synthesis of natural products, as well as in future studies of ecological processes involving plant-animal interactions, and taxonomy studies from the principal components analysis.

\section{MATERIALS AND METHODS}

Plant material: Entire flowers were obtained from plants of 13 species belonging to four Bromeliaceae genera: Aechmea bicolor L. B. Sm. (ESA 120990), Ae. bromeliifolia Baker ex Benth. \& Hook. f. (ESA 121275), Ae. distichantha Lem. (ESA 121275), Ae. fasciata Baker (ESA 120987), Ae. nudicaulis Griseb. (ESA 120991), Ananas macrodontes E. Morren (ESA 121286), An. comosus (L.) Merr. var. bracteatus (Lindl.) Coppens \& F. Leal 
(ESA 121284), An. comosus (L.) Merr. var. erectifolius (L.B.Sm.) Coppens \& F. Leal (ESA 121285), Alcantarea nahoumii (Leme) J.R. Grant (ESA 120986), Vriesea friburgensis Mez (ESA 121282), V. michaelii W. Weber (ESA 121280), V. paraibica Wawra (ESA 121276) and $V$. simplex Beer (ESA 120989), grown in a greenhouse, with flowers collected between the months of August 2011 and February 2012. All species presented anthesis between 6:30 and 8 am. Flowers were collected at anthesis $(8 \mathrm{am})$ from the middle part of inflorescences, in three replicates, each flower from a different plant. A representative plant of each species was deposited at the Escola Superior de Agricultura "Luiz de Queiroz" (ESALQ) University of São Paulo (USP) herbarium.

Solid-phase microextraction: This technique presents a low cost of execution, good repeatability, quickness, and is solvent-free. Collected flowers were immediately placed in $20 \mathrm{~mL}$ capped vials and allowed to equilibrate for $20 \mathrm{~min}$ at 37 for $20{ }^{\circ} \mathrm{C}$. Volatile compounds were collected from the headspace of each sample by solid-phase microextraction (SPME), using Supelco SPME fibers coated with divinylbenzene-polydimethylsiloxane (DVB/PDMS, $65 \mu \mathrm{m})$ during $20 \mathrm{~min}$ at $37{ }^{\circ} \mathrm{C}$. The fiber was then withdrawn into the needle and transferred for injection in the GC-MS system with splitless injection mode at $240{ }^{\circ} \mathrm{C}$ (Almeida, Gonçalves, Galego, Miguel, $\&$ Costa, 2006).

Gas chromatography and mass spectrometry: GC-MS analyses were conducted according to Custódio, Serra, Nogueira, Gonçalves, and Romano (2006) with modifications. The analyses of volatile compounds were performed on a gas chromatograph GC 2010 (Shimadzu Corp., Kyoto, Japan) coupled to a mass spectrometer QP 2010 Plus (Shimadzu Corp., Kyoto, Japan). Samples were separated using a capillary column (RTX-5MS $30 \mathrm{~m} \mathrm{x}$ $0.25 \mathrm{~mm} \times 0.25 \mu \mathrm{m})$. The temperature program started at $40{ }^{\circ} \mathrm{C}$ for $2 \mathrm{~min}$, increasing at $4{ }^{\circ} \mathrm{C}$ per min to $130{ }^{\circ} \mathrm{C}$, remaining at $130{ }^{\circ} \mathrm{C}$ for
$1 \mathrm{~min}$, increasing at $7^{\circ} \mathrm{C}$ per min to $230^{\circ} \mathrm{C}$, remaining at $230{ }^{\circ} \mathrm{C}$ for $4 \mathrm{~min}$, totaling $44 \mathrm{~min}$ of analysis. Helium was used as the carrier gas at linear velocity of $36.1 \mathrm{~cm} / \mathrm{s}$. The interface was maintained at $280{ }^{\circ} \mathrm{C}$ and the detector operated in the scanning mode $(\mathrm{m} / \mathrm{z} 45-450)$. Data integration was performed using the LabSolutions-GCMS Ver. 2.5 software (Shimadzu Corp., Kyoto, Japan).

Volatile identification and semi-quantification: The volatile compounds were identified by Wiley 138 and FFNSC libraries. The relative abundance of the compounds was calculated based on the MS results.

The data were subjected to the multivariate principal components analysis using Statistica (Statsoft, 2004).

\section{RESULTS}

HS-SPME/GC-MS analysis of the volatile profile emitted by flowers of 13 species belonging to four genera of Bromeliaceae was performed. A total of 80 compounds were extracted and 71 compounds were identified. Nine chemical groups were found in the identified compounds: alcohols, terpenoids, aldehydes, esters, ketones, ethers, furans, oxides, and styrene (Table 1). The compounds identified represented over $97 \%$ of the major components of this fraction. In Ae. bicolor, Ae. bromeliifolia, Ae. distichantha, Ae. fasciata, $V$. friburgensis and the three varieties of Ananas, over $99.45 \%$ of the compounds were identified, while in $V$. simplex $90.69 \%$ of the compounds were identified (Table 1, and supplementary material).

$V$. friburgensis showed the highest diversity of volatile compounds, with 31 chemicals, while Al. nahoumii showed only 14 compounds. The three varieties of Ananas contained the same 28 compounds in relatively similar abundance, as verified by principal component analysis (Fig. 1).

The group of terpenes showed the greatest number of compounds and the highest percentage in the fraction analyzed for most species, 


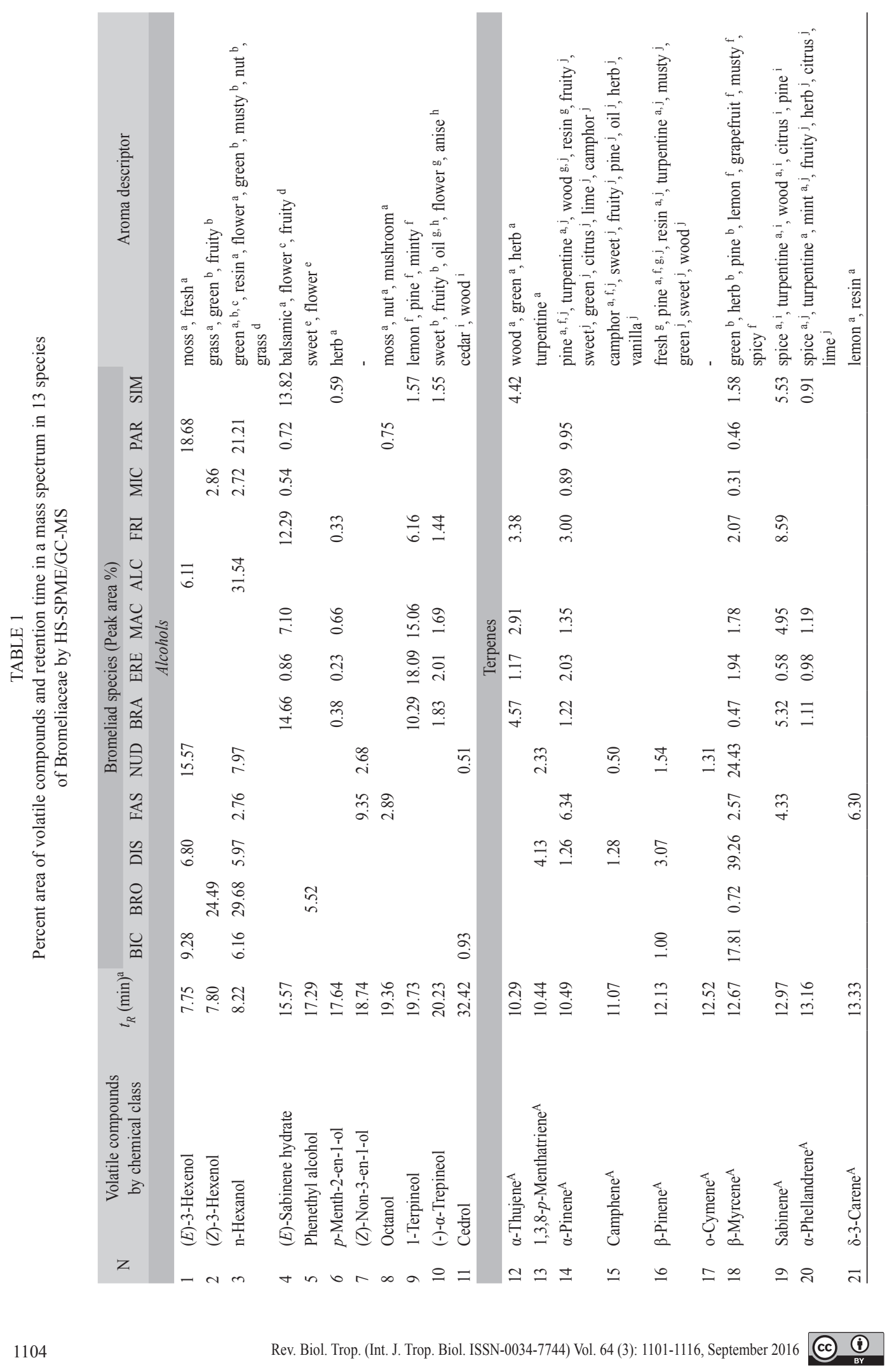




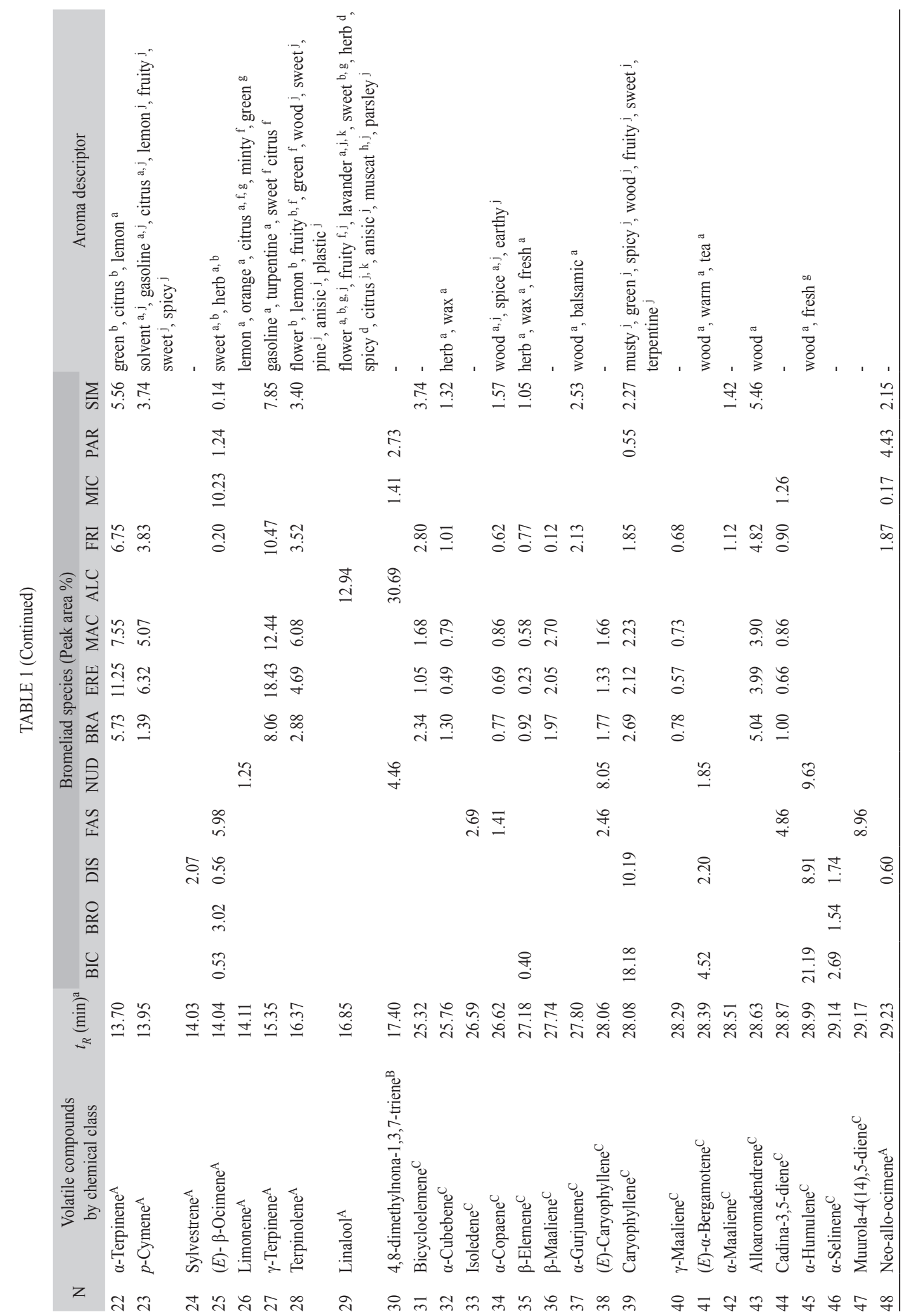




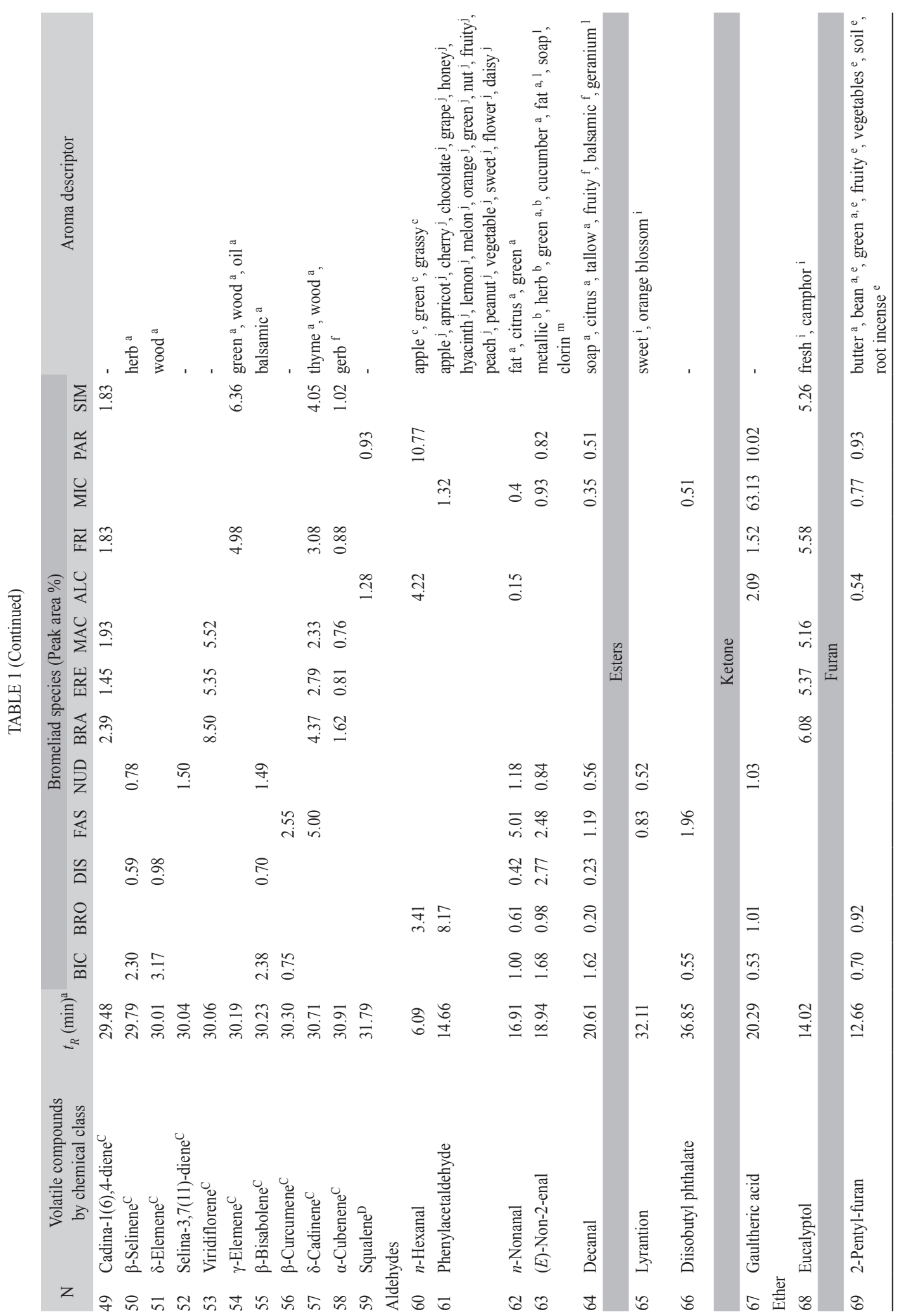




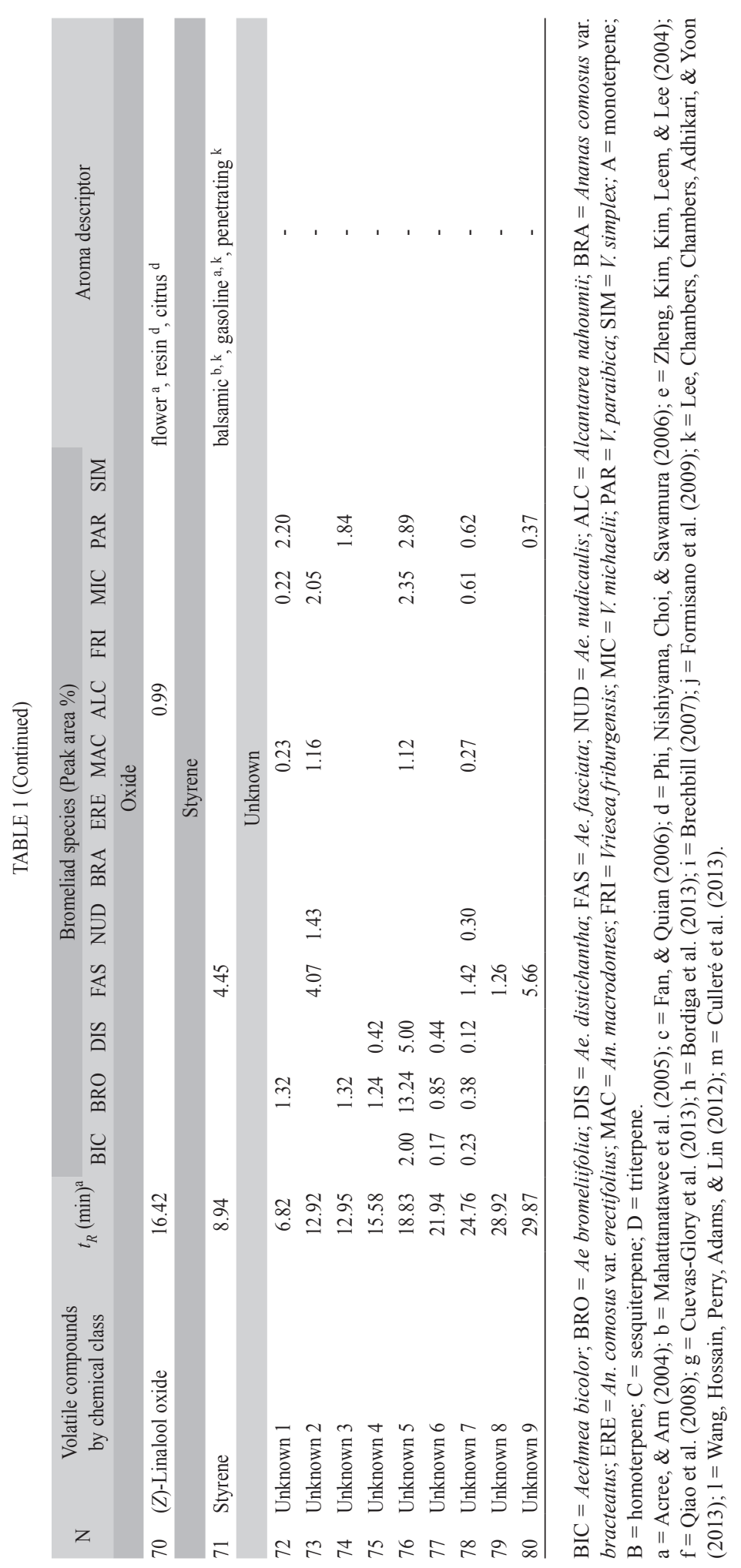




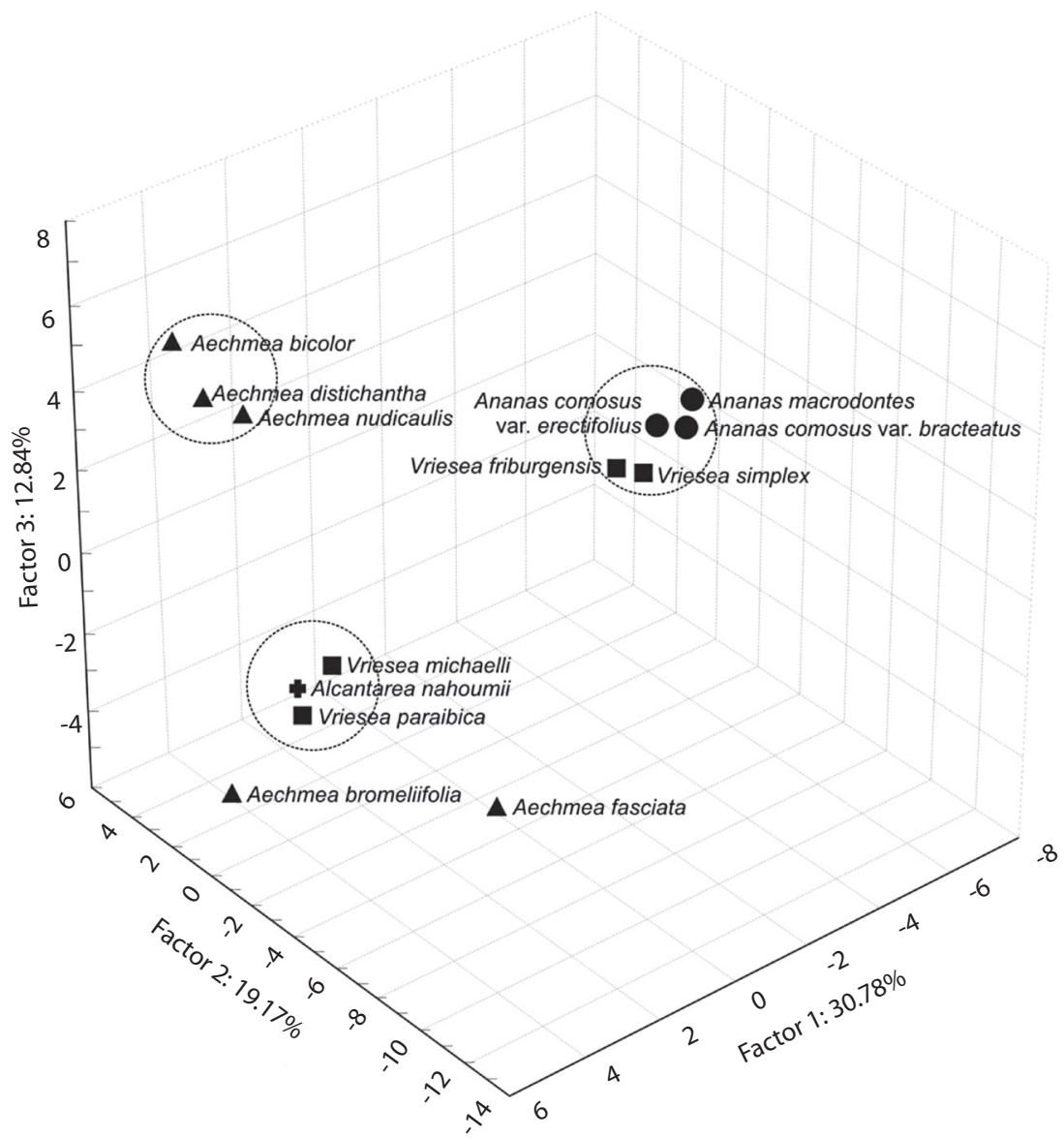

Fig. 1. Dispersion diagram of scores associated with the first three principal components obtained from the analysis of volatile compounds from flowers of 13 species of Bromeliaceae by HS-SPME/GC-MS.

such as Ae. bicolor (74.92\%), Ae. distichantha (77.54\%) and V. friburgensis (71.27\%). Among the Ananas varieties, terpenes corresponded to $69.01 \%$, representing $66.21 \%$ (A. comosus var. bracteatus), and $70.97 \%$ (A. comosus var. erectifolius) of the total composition. The compound $\beta$-myrcene was observed in all species except Al. nahoumii, with abundance ranging from 0.31 to $39.26 \%$ in $V$. michaelii, and Ae. distichantha, respectively. Linalool was only observed in Al. nahoumii, with approximately $12.94 \%$ of the total compounds found (Table 1, Fig. 2B, and supplementary material).

Eleven compounds belonging to the class of alcohols were identified, with a total abundance ranging from $6.12 \%$ to $59.69 \%$ in V. michaelli and Ae. bromeliifolia, respectively. Among them, the most abundant were $n$-hexanol, (Z)-hex-3-enol, $(E)$-sabinene hydrate and 1-terpineol (Table 1). $n$-Hexanol was identified in high abundance in most species studied, particularly Al. nahoumii (31.54\%), Ae. bromelifoliia $(29.68 \%)$ and $V$. paraibica $(21.21 \%)$.

Five aldehydes were identified among the compounds: $n$-hexanal, phenylacetaldehyde, n-nonanal, $(E)$-non-2-enal and decanal, the last three being found in all species of Aechmea analyzed. Phenylacetaldehyde was observed in Ae. bromeliifolia (8.17\%), and V. michaelli (1.32\%). 

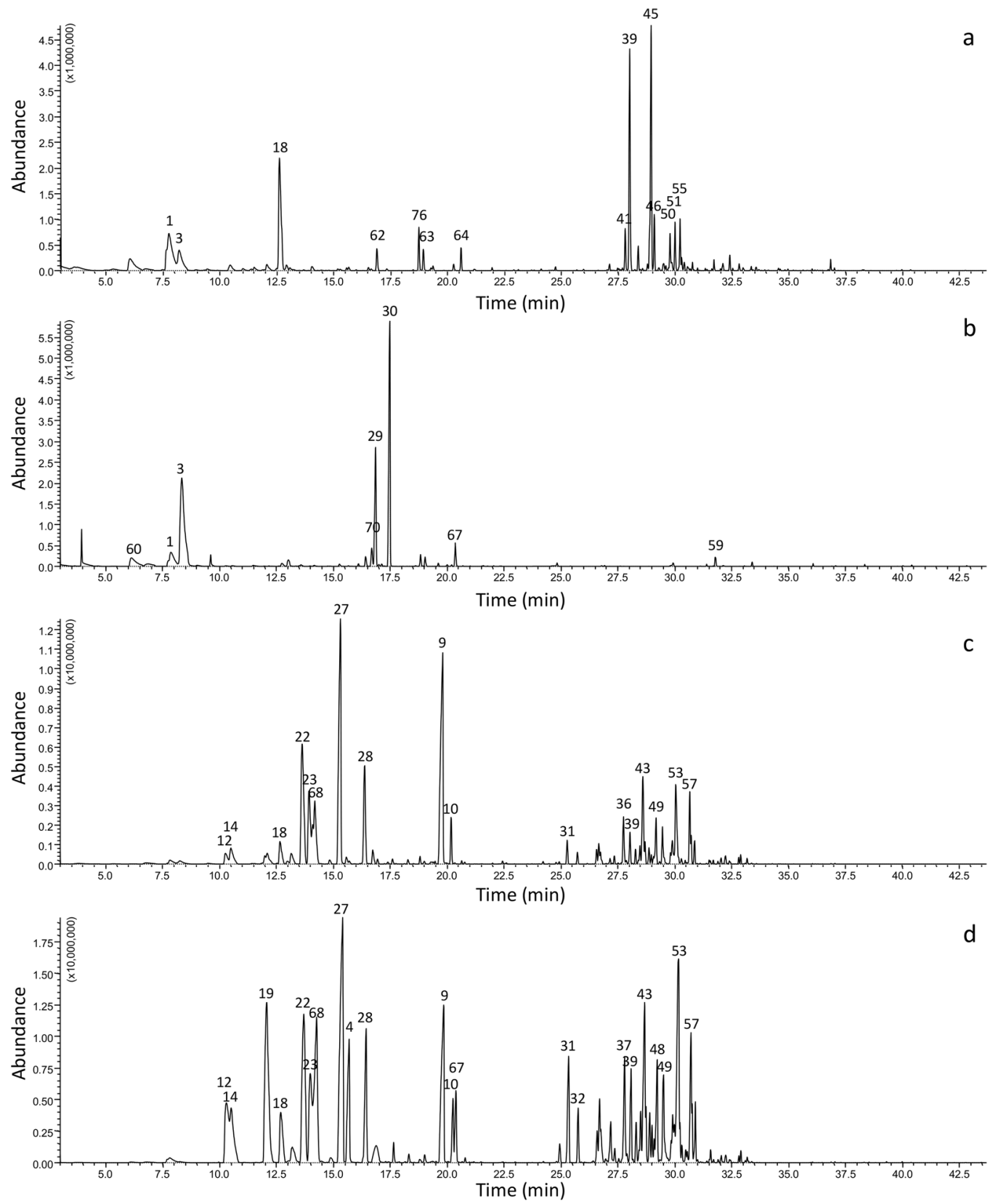

Fig. 2. Chromatographic profile obtained by HS-SPME/GC-MS of volatile compounds in flowers of Bromeliaceae, indicating the major compounds identified: A) Aechmea bicolor, B) Alcantarea nahoumii, C) Ananas comosus var. erectifolius, D) Vriesea friburgensis.

Gaultheric acid was found in highest abundance in $V$. michaelii $(63.13 \%)$, V. paraibica $(10.02 \%)$, while in the other species the values were below $2 \%$ (Table 1). Eucalyptol, an ether, was emitted by flowers of the three varieties of the genus Ananas (Fig. 2C), V. friburgensis (Fig. 2D) and $V$. simplex, with abundance ranging from 5.16 to $6.08 \%$ (Table 1). 
TABLE 2

Parameters obtained from the principal components analysis detailing the first five principal components obtained by HS-SPME/GC-MS from volatile compounds emitted by flowers of 13 species of Bromeliaceae

\begin{tabular}{lcccc}
\multicolumn{1}{c}{ Principal components } & Eigenvalue & $\begin{array}{c}\text { Total } \\
\text { variance \% }\end{array}$ & $\begin{array}{c}\text { Accumulated } \\
\text { eigenvalue }\end{array}$ & $\begin{array}{c}\text { Accumulated } \\
\text { percentage }\end{array}$ \\
PC 1: eucalyptol; alloaromadendrene; cadina-1(6),4-diene & 25.2458 & 30.7876 & 25.2458 & 30.7876 \\
PC 2: cadina-3,5-diene; unknown 7; muurola-4(14),5-diene & 15.7234 & 19.1749 & 40.9693 & 49.9625 \\
PC 3: $\alpha$-humulene; $(E)$ - $\alpha$ - bergamotene; $\beta$-bisabolene & 10.5336 & 12.8459 & 51.5029 & 62.8084 \\
PC 4 & 6.3267 & 7.7155 & 57.8296 & 70.5239 \\
PC 5 & 5.1625 & 6.2958 & 62.9922 & 76.8198 \\
\hline
\end{tabular}

The principal component analysis based on the volatile compounds of Bromeliaceae flowers from 13 species showed the first three components retaining $62.81 \%$ of the initial information (Table 2). This total variance is considered high, with high heterogeneity of the samples' chemical composition.

The correlation of each component and the variables allowed for the evaluation of the discriminatory power of this analysis. For PC1 $(30.78 \%)$, the variables that mostly influenced the separation of accessions based on volatile compounds were the presence of eucalyptol, alloaromadendren, and cadina-1(6),4-diene, with correlation values of $0.99,0.98$ and 0.98 , respectively. For PC2 (19.17\%), the variables with highest influence were cadina-3,5-diene, unknown 7 and muurola-4(14),5-diene, with correlation values of $0.96,0.93$ and 0.93 , respectively. For PC3 (12.85\%), the most significant variables were $\alpha$-humulene, $(E)$ - $\alpha$ - bergamotene and $\beta$-bisabolene, with correlations of $0.76,0.75$ and 0.75 , respectively.

The dispersion diagram of the scores of the first three main components (Fig. 1) showed three groups, and two isolated species, demonstrating the variability of volatile compounds among these bromeliad species.

\section{DISCUSSION}

This study demonstrated great variability of volatile compounds among the bromeliad species, with 71 compounds identified belonging to eight chemical groups, including alcohols, terpenoids, aldehydes, esters, ketones, ethers, furans, oxides, and styrene.

The presence of terpenoids in plants is associated with defense against herbivores, pathogenicity, and allelopathy to attract pollinators (Langenheim, 1994). Terpenes are associated with various fragrances, making them widely used to make perfumes and flavorings (Bauer, Garbe, \& Surburg, 2001).

The compound $\beta$-myrcene has been described in more than 200 plant species as being responsible for green, herb, pine, lemon, grapefruit, musty and spicy scents (Mahattanatawee, Rouseff, Filomena, \& Naim, 2005; Qiao et al., 2008). It is widely used in the cosmetic and pharmaceutical industries, as described by Behr and Johnen (2009). Linalool has been observed in tangerines and is responsible for their taste and aroma (Sawamura, Minhtu, Onishi, Ogawa, \& Choi, 2004).

Two other compounds observed in high abundance in most species studied here were: $\gamma$-terpinene, which has a citrusy, sweet (Acree \& Arn, 2004), gasoline and turpentine scent (Qiao et al., 2008); and $\alpha$-humulene, which has a woody (Acree \& Arn, 2004) and fresh scent (Cuevas-Glory, Ortiz-Vezquez, Sauri-Duch, \& Pino, 2013) and has been shown to have antiinflammatory properties. It is also found in the essential oil of Cordia verbenacea DC (Boraginaceae) (Fernandes et al., 2007).

Aldehydes have strong odors that recall citrus fruits, roses and fresh cut grass, being widely used in perfumery (Bauer et al., 2001). Phenylacetaldehyde is an aromatic compound also found in Fagopyrum esculentum Moench 
(Polygonaceae) (Janes, Kantar, Kreft, \& Prosen, 2009) and several species of flowers (Robert \& Meagher, 2002). This compound has long been used to attract various species of moths in traps for biological control (Robert, \& Meagher, 2002; Smith, Allen, \& Nelson, 1943; Cantelo, \& Jacobson, 1979), and has a floral/honey odor (Whetstine, Cadwallader, \& Drake, 2005).

High abundance of n-hexanol has also been observed in plum fruits, Prunus domestica L. (Rosaceae) (Gomez, Ledbetter, \& Hartsell, 1993), Caralluma europaea (Guss.) N.E.Br. (Apocynaceae) flowers (Formisano et al., 2009), Camellia sinensis (L.) Kuntze (Theaceae) (Han, Zhou, Cui, \& Fu, 2006) and essential oil of Pimenta guatemalensis (Lundell) Lundell (Chaverri \& Cicció, 2015). Jabalpurwala, Smoot and Rouseff (2009), studying volatile compounds in flowers of different species of Citrus, also observed high levels of n-hexanol in Citrus grandis (L.) Osbeck (Rutaceae), and correlated the levels with the pollination by bees, which is crucial for reproduction due to self-incompatibility.

Gaultheric acid belongs to the class of ketones and can be found in wines and plant species such as Gaultheria itoana Hayata (Ericaceae) (Chen et al., 2009). It is also abundant in the root bark of Securidaca longepedunculata Fresen (Polygalaceae), exerting a biocide effect against insects that feed on stored grains (Lognay, Marlier, Seck, \& Haubruge, 2000). The emission of volatile compounds with biocide effect can be related to pollination, exerting a repellent effect on some insect species.

Eucalyptol was also identified among the volatile compounds in African cycad (Encephalartos) (Zamiaceae) flowers (Suinyuy et al., 2013). Furans and oxides were present in a few species studied, but in low amounts.

Special patterns of scent in flowers can function as the same visual patterns, so differences in intensity and types of volatile compounds emitted, besides serving as guides for insects, help in the search for food rewards. A combination of chemical analyses of floral scents with field observations of the behavior of flower visitors is an effective way to demonstrate the effect of volatiles in the attraction of pollinators (Dobson, 1994).

The dispersion diagram of the first three main components scores showed V. michaelli, $V$. paraibica and Al. nahoumii forming the first group. These species are phylogenetically close, belonging to the subfamily Tillandsioideae (Barfuss, Samuel, Till, \& Stuessy, 2005; Givnish et al., 2011; Versieux et al., 2012), and Alcantarea traditionally being either considered as a subgenus of Vriesea, or a genus itself, both belonging to the tribe Vrieseeae (Grant, 1995). Floral morphology is one of the factors that influence the pollination syndrome (Aguilar-Rodríguez et al., 2014), these species present large flowers with yellow petals, and a tubular corolla. Similarities in composition of the flower volatiles produced among these species can be another factor to consider in establishing the relationship of these species.

Ae. bicolor, Ae. distichantha, and Ae. nudicaulis belong to the Bromelioideae subfamily, with similar flower morphological characteristics. They formed a second group according to their volatile compound composition. Faria, Wend and Brown (2004), studying the cladistic relationships of this genus, showed that Ae. distichantha and Ae. nudicaulis are very close in clade distribution. In addition, there are reports of common pollinators for these two species (Schmid, Schmid, Zillikens, Harter-Marques, \& Steiner, 2010; Scrok \& Varassin, 2011). There are very limited studies of Ae. bicolor, however morphological similarity is observed between its inflorescence and flower morphological characteristics and those of Ae. nudicaulis.

The dispersion diagram showed the two other Aechmea species studied, Ae. fasciata and Ae. bromeliifolia, isolated in the principal component analysis of the volatile compounds. This demonstrates the considerable variability of flower volatile compounds among this genus.

The third group included An. macrodontes, An. comosus var. erectifolius and An. comosus var. bracteatus and two species of Vriesea ( $V$. simplex and $V$. friburgensis). For Ananas, this grouping supports the morphological and 
taxonomic closeness within the genus, considering that the same 28 compounds were observed in Ananas flowers at similar values.

Considering that the flower volatile compound spectrum can be a plant strategy to attract pollinators, the two species of Vriesea may present pollination syndrome similarities with the genus Ananas, thus being grouped together in the principal component analysis. Hummingbirds are common pollinators between these two genus, which can explain the proximity of these species in the PCA results. Regarding Ananas ananassoides, Stah, Nepi, Galetto, Guimarães, and Machado (2012) observed the presence of two Trochilidae species, Hylocharis chrysura and Thalarania glaucopis, the latest also observed by Schmid et al. (2011) in V. friburgensis.

One of the reports of volatile compounds in bromeliads refers to $T$. macropetala, in which Aguilar-Rodríguez et al. (2014) identified nine volatile compounds, two of them similar to those found in this study, namely nonanal in the species Aechmea, Al. nahoumii and V. michaelii, and limonene in Ae. nudicaulis. Those authors pointed out that the pollination syndrome is not necessarily related to a single compound, such as dimethyl disulphide, which although absent in $T$. macropetala, did not prevent the visit of pollinating bats. In this case, of the nine compounds identified by the researchers, six are also present in other species pollinated by bats. In Werauhia gladiolifora, also pollinated by bats, Bestmann, Winkle, and Helversen (1997) observed 12 volatile compounds, five of them common to those observed in the species of the present work ( $\alpha$-Pinene, $\beta$-Pinene, 4,8-dimethyl-1,3,7nonatriene, $\beta$-Myrcene, Limonene, $\alpha$-Copaene) and two common to T. macropetala ( $\beta$-Pinene e Limonene) a species pollinated by bats (Aguilar-Rodríguez et al., 2014).

Finally, it is important to highlight that the aroma composition varies throughout the day and this issue is important in attracting pollinators (Balao, Herrera, Talavera, \& Dötterl, 2011; Aguilar-Rodríguez et al., 2014). Dötterl, Jahreb, Jhumur, and Jürgens (2012) evaluated the volatile compound dynamics throughout the $24 \mathrm{~h}$ in which the flowers were open, observing a variation of these compounds, thus enabling a greater diversity of pollinators, and thus ensuring the reproductive success of the species. In our study, the flowers were collected at anthesis, which occurred between 6:30 and 8 a.m. for all species. Further experiments on the volatile compounds dynamics throughout the day may be interesting for pollination attraction studies in these species.

We identified 71 different volatile compounds, some of them having significant importance in the food, cosmetic, perfume, chemical and pharmaceutical industries. The variation in the odor profile observed of Bromeliaceae in this study shows complex variability. Current taxonomy and pollination syndrome studies can adequately explain the variation in volatile compounds among species. Characterization of these compounds in Bromeliaceae may clarify some problems in taxonomy. Further studies using more species from different genera and detailed morphological information and volatile composition associated with their pollinators can clarify the attraction of pollinators by specific odor compounds.

\section{ACKNOWLEDGMENTS}

The authors acknowledge Fundação de Amparo à Pesquisa do Estado de São Paulo, FAPESP (2009/18255-0), and Conselho Nacional de Desenvolvimento Cientifico e Tecnológico, CNPq (476.131/2008-1), for financial support. APM also acknowledges CNPq for research fellowships (305.785/20087 and 310.612/2011-0).

\section{RESUMEN}

Perfil de compuestos volátiles de las flores en las Bromeliaceae. Los compuestos volátiles tienen un papel vital en el ciclo de vida de las plantas. Poseen actividad antimicrobiana y anti-herbivoría biológica y una gran importancia en la industria de alimentos, cosméticos, perfumes, productos químicos y farmacéuticos. Este estudio tuvo como objetivo identificar los compuestos volátiles de trece flores de especies, pertenecientes a cuatro géneros 
de Bromeliaceae utilizando microextracción en fase sólida mediante cromatografía de gases hifenada con espacio de cabeza acoplada a espectrometría de masas. Se han identificado setenta y un diferentes compuestos volátiles pertenecientes a nueve grupos. Los compuestos identificados representaron más del $97 \%$ de los componentes principales en Aechmea bicolor, Ae. bromeliifolia, Ae. distichantha, Ae. fasciata, Vriesea friburgensis, $99 \%$ en las variedades de Ananas y $90 \%$ en $V$. Simplex. $V$. friburgensis mostró la mayor diversidad de compuestos volátiles con 31, mientras que en Al. nahoumii se han encontrado sólo 14 compuestos. Las tres variedades de Ananas presentan los mismos 28 compuestos en cantidades relativamente similares, lo que se confirmó por el análisis de componentes principales. Estudios taxonómicos y síndromes de polinización disponibles podrían explicar la variación de los compuestos volátiles entre especies.

Palabras clave: bromelia, cromatografía de gases, espacio de cabeza, espectrometría de masas, análisis de componentes principales, terpenoides.

\section{REFERENCES}

Acree, T., \& Arn, H. (2004). Flavornet and human odor space. Retrieved from http://www.flavornet.org.

Aguilar-Rodríguez, P. A., MacSwiney, G. M. C., Krömer, T., García-Franco, J. G., Knauer, A., \& Kessler, M. (2014). First record of bat-pollination in the speciesrich genus Tillandsia (Bromeliaceae). Annals of Botany, 113, 1047-1055.

Almeida, V., Gonçalves, V., Galego, L., Miguel, G., \& Costa, M. (2006). Volatile constituents of leaves and flowers of Thymus mastichina by Headspace Solid-Phase Microextraction. Acta Horticulturae, 723, 239-242.

Arab, A., \& Bento, J. M. S. (2006). Plant volatiles: new perspectives for research in Brazil. Neotropical Entomology, 35(2), 151-158.

Araujo, A. C., Fischer, E., \& Sazima, M. (2004). As Bromélias na região do Rio Verde. In O. Marques, \& W. Duleba (Eds.), Estação Ecológica Juréia-Itatins: ambiente fisico, flora e fauna (pp. 162-171). Ribeirão Preto, SP: Holos Editora.

Balao, F., Herrera, J., Talavera, S., \& Dötterl, S. (2011). Spatial and temporal patterns of floral scent emission in Dianthus inoxianus and electroantennographic responses of its hawkmoth pollinator. Phytochemistry, 72(7), 601-609.

Barfuss, M. H. J., Samuel, R., Till, W., \& Stuessy, T. F. (2005). Phylogenetic relationships in subfamily Tillandsioideae (Bromeliaceae) based on DNA sequence data from seven plastid regions. American Journal of Botany, 92(2), 337-351.
Bauer, K., Garbe, D., \& Surburg, H. (2001). Common Fragrance and Flavor Materials. Weinheim: Wiley-VCH.

Behr, A., \& Johnen, L. (2009). Myrcene as a natural base chemical in sustainable chemistry: A critical review. Chemistry \& Sustentability, Energy \& Materials, 2(12), 1072-1095.

Benzing, D. H. (2000). Bromeliaceae: Profile an Adaptive Radiation. Cambridge: Cambridge University Press.

Bestmann, H. J., Winkler, L., \& von Helversen, O. (1997). Headspace analysis of volatile flower scent constituents of bat-pollinated plants. Phytochemistry, 46(7), 1169-1172.

Bordiga, M., Rinaldi, M., Locatelli, M., Piana, G., Travaglia, F., Coïsson, J. D., \& Arlorio, M. (2013). Characterization of Muscat wines aroma evolution using comprehensive gas chromatography followed by a post-analytic approach to $2 \mathrm{D}$ contour plots comparison. Food Chemistry, 140(1-2), 57-67.

Brechbill, G. O. (2007). Classifying aroma chemicals. New Jersey: Fragrance Book Inc.

Canela, M. B. F., \& Sazima, M. (2005). The pollination of Bromelia antiacantha (Bromeliaceae) in Southeastern Brazil: Ornithophilous versus Melittophilous features. Plant Biology, 7(4), 411-416.

Cantelo, W. W., \& Jacobson, M. (1979). Phenylacetaldehyde attracts moths to bladder flower and to blacklight traps. Environmental Entomology, 8(3), 444-447.

Chaverri, C., \& Cicció, J. F. (2015). Leaf and fruit essential oil compositions of Pimenta guatemalensis (Myrtaceae) from Costa Rica. Revista de Biología Tropical, 63(1), 303-311.

Chen, C. Y., Lin, R. J., Huang, J. C., Wu, Y. H., Cheng, M. J., Hung, H. C., \& Lo, W. L. (2009). Chemical constituents from the whole plant of Gaultheria itoana Hayata. Chemistry \& Biodiversity, 6(10), 1737-1743.

Cheng, H. (2010). Volatile flavor compounds in yogurt: a review. Critical Reviews in Food Science and Nutrition, 50(10), 938-950.

Cuevas-Glory, L., Ortiz-Vazquez, E., Sauri-Duch, E., \& Pino, J. A. (2013). Characterization of aroma-active compounds in sugar apple (Annona squamosa L.). Acta Alimentaria, 42(1), 102-108.

Culleré, L., Simón, B. F., Cadahía, E., Ferreira, V., Hernández-Orte, P., \& Cacho, J. (2013). Characterization by gas chromatography-olfactometry of the most odoractive compounds in extracts prepared from acacia, chestnut, cherry, ash and oak woods. Food Science and Technology, 53(1), 240-248. 
Custódio, L., Serra, H., Nogueira, J. M. F., Gonçalves, S., \& Romano, A. (2006). Analysis of the volatiles emitted by whole flowers and isolated flower organs of the carob tree using HS-SPME-GC/MS. Journal of Chemical Ecology, 32(5), 929-942.

Darjazi, B. B. (2011). A comparison of volatile components of flower of page mandarin obtained by ultrasoundassisted extraction and hydrodistillation. Journal of Medicinal Plants Research, 5(13), 2839-2847.

Dobson, H. E. H. (1994). Floral volatiles in insect biology. In E. A. Bernays (Ed.), Insect-plant interactions (pp. 47-81). Boca Raton, FL: CRC Press.

Dötterl, S., Jahreib, K., Jhumur, U. S., \& Jürgens, A. (2012). Temporal variation of flower scent in Silene otitis (Caryophyllaceae): a species with a mixed pollination system. Botanical Journal of the Linnean Society, 169(3), 447-460.

Dudareva, N., \& Pichersky, E. (2006). Biology of floral scent. Boca Raton, FL: CRC Press.

Dudareva, N., Pichersky, E., \& Gershenzon, J. (2004) Biochemistry of plant volatiles. Plant Physiology, 135(4), 1893-1902.

Fan, W., \& Quian, M. C. (2006). Characterization of aroma compounds of Chinese "Wuliangye" and "Jiannanchun" liquors by aroma extract dilution analysis. Journal of Agricultural and Food Chemistry, 54(7), 2695-2704.

Faria, A. P. G., Wendt, T., \& Brown, G. K. (2004). Cladistic relationships of Aechmea (Bromeliaceae: Bromelioideae) and allied genera. Annals of the Missouri Botanical Garden, 91(2), 303-319.

Fernandes, E. S., Passos, G. S., Medeiros, R., Cunha, F. M., Ferreira, J., Campos, M. M., ..., \& Calixto, J. B. (2007). Anti-inflammatory effects of compounds alpha-humulene and (-)-trans-caryophyllene isolated from the essential oil of Cordia verbenacea. European Journal of Pharmacology, 569(3), 228-236.

Formisano, C., Senatore, F., Porta, G. D., Scognamiglio, M., Bruno, M., Maggio, A., ..., \& Sajeva, M. (2009). Headspace volatile composition of the flowers of Caralluma europaea N.E.Br. (Apocynaceae). Molecules, 14(11), 4597-4613.

Gerlach, G., \& Schill, R. (1991). Composition of Orchid Scents Attracting Euglossine Bees. Botanica Acta, 104(5), 385-391.

Givnish, T. J., Barffus, M. H. J., Ee, B. E., Riina, R., Schulte, K., Horres, R., ..., \& Sytsma, K. J. (2011). Phylogeny, adaptative radiation, and historical biogeography in Bromeliaceae: insights from an eightlocus plastid phylogeny. American Journal of Botany, 98(5), 872-895.
Gomez, E., Ledbetter, C. A., \& Hartsell, P. L. (1993). Volatile compounds in apricot, plum, and their interspecific hybrids. Journal of Agricultural and Food Chemistry, 41(10), 1669-1676.

Grant, J. R. (1995). Addendum to "The resurrection of Alcantarea and Werauhia, a new genus" (Bromeliaceae: Tillandsioideae). Phytologia, 78(2), 119-123.

Hammer, K. A., Carson, C. F., \& Riley, T. V. (2003). Antifungal activity of the components of Melaleuca alternifolia (tea tree) oil. Journal of Applied Microbiology, 95(4), 853-860.

Han, B., Zhou, P., Cui, L., \& Fu, J. (2006). Characterization of the key aromatic constituents in tea flowers of elite Chinese tea cultivar. International Society of Tea Science, 6, 31-36.

Huang, C. J., Lee, S. L., \& Chou, C. C. (2001). Production of 2-phenylethanol, flavor ingredient, by Pichia fermentans L-5 under various culture conditions. Food Research International, 34(4), 277-282.

Jabalpurwala, F. A., Smoot, J. M., \& Rouseff, R. L. (2009). A comparison of Citrus blossom volatiles. Phytochemistry, 70(11-12), 1428-1434.

Janes, D., Kantar, D., Kreft, S., \& Prosen, H. (2009). Identification of buckwheat (Fagopyrum esculentum Moench) aroma compounds with GC-MS. Food Chemistry, 112(1), 120-124.

Kessler, A., Halitschke, R., \& Poveda, K. (2011). Herbivory-mediated pollinator limitation: negative impacts of induced volatiles on plant-pollinator interactions. Ecology, 92(9), 1769-1780.

Kessler, M., \& Krömer, T. (2000). Patterns and ecological correlates of pollination modes among bromeliad communities of Andean Forests in Bolivia. Plant Biology, 2(6), 659-669.

Knudsen, J. T., Tollsten, L., Groth, I., Bergström, G., \& Raguso, R. A. (2004) Trends in floral scent chemistry in pollination syndromes: floral scent composition in hummingbird-pollinated taxa. Botanical Journal of the Linnean Society, 146(2), 191-199.

Knudsen, J., \& Tollsten, L. (1995). Floral scent in bat-pollinated plants: a case of convergent evolution. Botanical Journal of the Linnean Society, 119(1), 45-57.

Knudsen, J. T., \& Gershenzon, J. (2006). The chemistry diversity of floral scent. In N. Dudareva, \& E. Pichersky (Eds.), Biology of Floral Scent (pp. 27-52). Boca Raton, FL: CRC Press.

Langenheim, J. H. (1994). Higher plant terpenoids: A phytocentric overview of their ecological roles. Journal of Chemical Ecology, 20(6), 1223-1280. 
Lee, J., Chambers, D. H., Chambers, E., Adhikari, K., \& Yoon, Y. (2013). Volatile aroma compounds in various brewed green teas. Molecules, 18(8), 10024-10041.

Liu, S. H., Wei, C. B., Sun, G. M., \& Zang, X. P. (2008). Analysis of aroma components of three pineapple cultivars. Food Science, 29(12), 614-617.

Lognay, G.,B Marlier, M., Seck, D., \& Haubruge, E. (2000). The occurrence of 2-hydroxy-6-methoxybenzoic acid methyl ester in Securidaca longepedunculata Fresen root bark. Biotechnology, Agronomy, Society and Environment, 4(2), 107-110.

Lucas-Barbosa, D., Loon, J. J. A., \& Dicke, M. (2011). The effects of herbivore-induced plant volatiles on interactions between plants and flower-visiting insects. Phytochemisty, 72(13), 1647-1654.

Luther, H. E. (2012). An alfabetical list of Bromeliad binomials (13th ed.). Sarasota, FL: Sarasota Bromeliad Society and Marie Selby Botanical Gardens.

Mahattanatawee, K., Rouseff, R., Filomena, V. M., \& Naim, M. (2005). Identification and aroma impact of norisoprenoids in orange juice. Journal of Agricultural and Food Chemistry, 53(2), 393-397.

Nogueira, P. C. L., Bittrich, V., Shepherd, G. J., Lopes, A. V., \& Marsaioli, A. J. (2001). The ecological and taxonomic importance of flower volatiles of Clusia species (Guttiferae). Phytochemistry, 56(5), 443-452.

Paibon, W., Yimnoi, C. A., Tembab, N., Boonlue, W., Jampachaisri, K., Nuengchamnong, N., ..., \& Ingkaninan, K. (2011). Comparison and evaluation of volatile oils from three different extraction methods for some Thai fragrant flowers. International Journal of Cosmetic Science, 33(2), 150-156.

Parra-Garcés, M. I., Caroprese-Araque, J. F., Arrieta-Prieto, A., \& Stashenko, E. (2010). Morfología, anatomía, ontogenia y composición química de metabolites secundarios en inflorescencias de Lippia alba (Verbenaceae). Revista Biología Tropical, 58(4), 1533-1548.

Phi, N. T. L., Nishiyama, C., Choi, H. S., \& Sawamura, M. (2006). Evaluation of characteristic aroma compounds of Citrus natsudaidai Hayata (Natsudaidai) cold-pressed pell oil. Bioscience, Biotechnology, and Biochemistry, 70(8), 1832-1838.

Pichersky, E., \& Gershenzon, J. (2002). The formation and function of plant volatiles: perfumes for pollinator attraction and defense. Current Opinion in Plant Biology, 5(3), 237-243.

Qiao, Y., Xie, B. J., Zhang, Y., Zhang, Y., Fan, G., Yao, X. L., \& Pan, S. Y. (2008). Characterization of aroma active compounds in fruit juice and peel oil of Jinchen sweet orange fruit (Citrus sinensis (L.) Osbeck) by GC-MS and GC-O. Molecules, 13(6), 1333-1344.
Robert, L., \& Meagher, J. R. (2002). Trapping noctuid moths with synthetic floral volatile lures. Entomologia Experimentalis et Applicata, 103(3), 219-226.

Sawamura, M., Minhtu, N. T., Onishi, Y., Ogawa, E., \& Choi, H. S. (2004). Characteristic odor components of Citrus reticulata Blanco (Ponkan) cold pressed oil. Bioscience, Biotechnology, and Biochemistry, 68(8), 1690-1697.

Sazima, I., Vogel, S., \& Sazima, M. (1989). Bat pollination of Encholirium glaziovii, a terrestrial bromeliad. Plant Systematics and Evolution, 168(3), 167-179.

Sazima, M., Buzato, S., \& Sazima, I., 1995. Bat pollination of Vriesea in Southeastern Brazil. Bromelia, 2, 29-37.

Schmid, S., Schmid, V. S., Zillikens, A., \& Steiner, J. (2011). Diversity of flower visitors and their role for pollination in the ornithophilous bromeliad Vriesea friburgensis in two different habitats in Southern Brazil. Ecotropica, 17(1), 91-102.

Schmid, S., Schmid, V. S., Zillikens, A., Harter-Marques, B., \& Steiner, J. (2011). Bimodal pollination system of the bromeliad Aechmea nudicaulis including hummingbirds and bees. Plant Biology, 13(1), 41-50.

Scrok, G. J., \& Varassin, I. G. (2011). Reproductive biology and pollination of Aechmea distichantha Lem. (Bromeliaceae). Acta Botanica Brasilica, 25(3), 571-576.

Siqueira Filho, J. A. (1998). Biologia floral de Hohenbergia ridleyi (Baker) Mez. Bromelia, 5, 3-13.

Siqueira Filho, J. A., \& Machado, I. C. S. (2001). Biologia reprodutiva de Canistrum aurantiacum E. Morren (Bromeliaceae) em remanescente da Floresta Atlântica, Nordeste do Brasil. Acta Botanica Brasilica, 15(3), 427-443.

Smith, C. E, Allen, N., \& Nelson, O. A. (1943). Some chemotropic studies with Autographa spp. Journal of Economic Entomology, 36(4), 619-621.

Stahl, J. M., Nepi, M., Galetto, L., Guimarães, E., \& Machado, S. R. (2012). Functional aspects of floral nectar secretion of Ananas ananassoides, an ornithophilous bromeliad from the Brazilian savanna. Annals of Botany, 109(7), 1243-1252.

Statsoft Inc. (2004). Statistica 7.0. Tulsa, OK: Statsoft ${ }^{\circledR}$

Suinyuy, T. N., Donaldson, J. S., \& Johnson, S. D. (2013). Variation in the chemical composition of cone volatiles within the African cycad genus Encephalartos. Phytochemistry, 85(1), 82-91.

Tokitomo, Y., Steinhaus, M., Buttner, A., \& Schieberle, P. (2005). Odor-active constituents in fresh pineapple (Ananas comosus [L.] Merr.) by quantitative and sensory evaluation. Bioscience, Biotechnology, and Biochemistry, 69(7), 1323-1330. 
Versieux, L. M., Barbará, T., Wanderley, M. G. L., Calvente, A., Fay, M. F., \& Lexer, C. (2012). Molecular phylogenetics of the Brazilian giant bromeliads (Alcantarea, Bromeliaceae): implications for morphological evolution and biogeography. Molecular Phylogenetics and Evolution, 64(1), 177-189.

Wang, Y., Hossain, D., Perry, P. L., Adams, B., \& Lin, J. (2012). Characterization of volatile and aromaimpact compounds in persimmon (Diospyros kaki L., var. Triumph) fruit by GC-MS and GC-O analyses. Flavour and Fragrance Journal, 27(2), 141-148.

Wei, C. B., Liu, S. H., Liu, Y. G., Lv, L. L., Yang, W. X., \& Sun, G. M. (2011). Characteristic aroma compounds from different pineapple parts. Molecules, 16(6), 5104-5112.

Whetstine, M. E. C., Cadwallader, K. R., \& Drake, M. (2005). Characterization of aroma compounds responsible for the rosy/floral flavor in cheddar cheese. Journal of Agricultural and Food Chemistry, 53(8), 3126-3132.

Zheng, C. H., Kim, T. H., Kim, K. H., Leem, Y. H., \& Lee, H. J. (2004). Characterization of potent aroma compounds in Chrysanthemum coronarium L. (Garland) using aroma extract dilution analysis. Flavour and Fragrance Journal, 19(5), 401-405. 